\title{
Assessment process in dental schools: perspectives and teaching challenges
}

\section{Processo de avaliação nas faculdades de odontologia: perspectivas e desafios do ensino}

\author{
Verydianna Frota CARNEIRO1 iD https://orcid.org/0000-0001-8961-8349 \\ Alice Maria Correia PEQUENO1 (iD https://orcid.org/0000-0002-4248-1610 \\ Maria de Fátima Antero Sousa MACHADO² iD https://orcid.org/0000-0002-2541-8441 \\ Dulce Maria de Lucena AGUIAR ${ }^{3}$ iD https://orcid.org/0000-0002-3797-906X \\ Cleide CARNEIRO1 (iD https://orcid.org/0000-0002-7095-1691 \\ Rithianne Frota CARNEIRO4 (iD https://orcid.org/0000-0003-4147-9364
}

\begin{abstract}
Objective: To analyze the teachers' view on the difficulties and the contribution of the assessment process to an undergraduate program in dentistry at a university in Fortaleza, Ceará. Methods: This is a descriptive research with a qualitative approach. Research subjects were undergraduate dentistry professors with teaching experience in such program of five years or more. Data collection was carried out from September to October 2014, through a documentary analysis of, among others, the pedagogical political project and a semi-structured interview. A thematic review was adopted to interpret data. Results: The main difficulty in the assessment was quantifying the student's performance. The influence of the assessment on professional education depends on the understanding of the assessment process and the acquired experience. Teachers recognize the punishing and pushing effect that still remain in such process and requires a major change. Conclusion: Teachers should establish assessment criteria guided by their teaching goals, without forgetting the profile of graduates from their institutions. Besides, assessment should encourage learning by coping with unfavorable emotions, restoring confidence and the learning ability. The course should be based on a curricular pedagogical project supported by guiding principles, in order to drive the assessment practice and avoid any seclusion.
\end{abstract}

Indexing terms: Dentistry. Education, higher. Educational measurement.

\section{RESUMO}

Objetivo: Analisar a visão dos professores sobre as dificuldades e a contribuição do processo de avaliação para o curso de graduação em odontologia de uma universidade de Fortaleza, Ceará. Métodos: Pesquisa descritiva, com abordagem qualitativa. Os sujeitos da

\footnotetext{
$\boldsymbol{\nabla v} \boldsymbol{\nabla}$

1 Universidade Estadual do Ceará, Mestrado em Ensino na Saúde. Av. Dr. Silas Munguba, 1700, Campus do Itaperi, Fortaleza, CE, Brasil. Correspondence to: VF Carneiro. E-mail: <verydianna_1@hotmail.com>.

2 Universidade Regional do Cariri. Crato, CE, Brasil.

3 Universidade de Fortaleza, Faculdade de Odontologia. Fortaleza, CE, Brasil.

4 Universidade Estadual do Ceará, Doutorado em Saúde Coletiva. Fortaleza, CE, Brasil.

$\boldsymbol{\nabla} \boldsymbol{\nabla} \boldsymbol{\nabla}$

How to cite this article

Carneiro VF, Pequeno AMC, Machado MFAS, Aguiar DML, Carneiro C, Carneiro RF. Assessment process in dental schools: perspectives and teaching challenges. RGO, Rev Gaúch Odontol. 2020;68:e20200022. http://dx.doi.org/10.1590/1981-863720200002220180004
} 
pesquisa foram professores de graduação em odontologia com experiência de ensino nesse programa de cinco anos ou mais. A coleta de dados foi realizada no período de setembro a outubro de 2014, por meio de uma análise documental, entre outros, do projeto político pedagógico e de uma entrevista semiestruturada. Uma revisão temática foi adotada para interpretar os dados. Resultados: A principal dificuldade na avaliação foi quantificar o desempenho do aluno. A influência da avaliação na formação profissional depende da compreensão do processo de avaliação e da experiência adquirida. Os professores reconhecem o efeito punitivo e agressivo que ainda permanece nesse processo e requer uma grande mudança. Conclusão: Os professores devem estabelecer critérios de avaliação orientados por seus objetivos de ensino, sem esquecer o perfil dos egressos de suas instituições. Além disso, a avaliação deve incentivar o aprendizado, lidando com emoções desfavoráveis, restaurando a confiança e a capacidade de aprendizado. O curso deve basear-se em um projeto pedagógico curricular apoiado em princípios orientadores, a fim de orientar a prática de avaliação e evitar qualquer reclusão.

Termos de indexação: Odontologia. Educação superior. Avaliação educacional.

\section{INTRODUCTION}

Over the years, the meaning attached to the assessment process has changed. Traditionally, assessment serves as an exam, highlighting cognitive aspects, especially memorization; Under this perspective, students should strictly reproduce what they have been taught [1]. Difficulties of students in relation to the acquired knowledge are disregarded, as well as the concern with an appropriate methodology in the teaching and learning process, one that could promote the understanding of learned contents [2].

More recently, the assessment process has been used as an instrument to understand the students' learning stage, in order to support sufficient and satisfactory decisions to make them move forward in their learning processes [3]. The assessment should focus on building knowledge rather than on the product, in the sense of a simple score or test result $[4,5]$.

The assessment carries a historical weight, representing different visions of society, education and curriculum $[6,7]$. It is key to take into account the role of contextual variables in the teaching / learning process, as well as in the assessment process [8]. It will be up to the schools to define an assessment model that will enable them to meet not only legal requirements, but also to play their role as generators, systematizers and socializers of knowledge [9].

According to the Law of Guidelines and Basis of National Education, it is the teacher's responsibility to participate in the preparation of the pedagogical proposal of the educational institution; to integrate the planning and assessment periods and to establish recovery strategies for low performance students [10].

The National Curricular Guidelines of the Dentistry Major guide and provide curricular notions that should be constantly monitored and evaluated, thus leading to an improvement. The course's curriculum should contemplate mechanisms capable of giving a degree of flexibility that allow students to develop skills, interests and potentials [11]. It should be emphasized that the undergraduate dentistry course should use methodologies and criteria for monitoring and assessing the teaching-learning process, in accordance with the curricular dynamics of each institution [11].

The idea of a traditional and qualifying assessment still prevails in the historical context of educational assessment in Brazil, and is therefore one of the factors responsible for academic failure and dropout [12]. However, what one sees is the continuance of a classical, purely technical dental training approach, without any interaction between courses and with few practical lessons [13]. Formative assessment has featured as a bureaucratic systemic requirement, a place of authoritarian, threatening and selective practices in the student-teacher relation. In fact, what we see is not quite an assessment, but rather an exam, which serves only to rank students according to their grades, scores or "fail/pass" judgment. Such an approach restricts the assessment and poses the risk of causing serious losses to learners [3].

The teaching staff should be trained to establish criteria that can make up a formative evaluation, capable of creating moments of reflection about the intention and purpose of the process and then make the appropriate decisions [14].

There is a need for new studies analyzing the perception of all stakeholders in dentistry courses, which could identify problems and hurdles regarding the establishment of integrated teaching, research and extension practices aimed at strengthening the public health care system and improving the national health condition. Thus, it is necessary to include programs that could develop assessment skills in both teachers and 
students, in the constant search for consistency with curriculum-based pedagogical assumptions [15].

In order to deepen knowledge and inspire changes in the formative assessment in higher education programs, this research proves to be necessary, as it will contribute to rethink the assessment process carried out in undergraduate dentistry courses, its difficulties and its potential for student development. This article aims at analyzing the teachers' view on the difficulties and the contribution of the assessment process of undergraduate program in dentistry at a university in Fortaleza, Ceará.

\section{METHODS}

This study refers to a social research that employs a qualitative, descriptive and documentary approach.

The study took place in a traditional undergraduate dentistry course at a private university in Fortaleza (CE), which has trained over 1,700 graduates until 2018, particularly dental surgeons. The institution has an inclusive curriculum, with a formative process based on humanistic principles, and it trains qualified professionals, both from an individual and a collective point of view, who see the patients as a whole in their physical, psychic and social aspects.

The training of dental surgeons in Ceará began on March 12, 1916 with the foundation of the first School of Dentistry \& Pharmacy of the state, which after the higher education reform in 1969, started to operate as a dentistry course at the Federal University of Ceará and was therefore the first institution of the state to offer an undergraduate dentistry course. The second dentistry course of the state, object of the present research, began its activities in February 1995. With the expansion of higher education in Brazil, from 2006 onwards, new undergraduate dentistry programs arose in Ceará, increasing the number of dental education institutions in the state.

The research subjects were undergraduate dentistry professors at the teaching institution at issue, because as an integral part of the assessment process, they must build and propose assessment strategies, according to the institutional pedagogical guidelines in order to improve students' performance.

As inclusion criteria, we have selected professors who work 40 hours a week and teach core courses in the last three years of the dental program and have a teaching experience of five years or more in the institution at issue.

The 40 hours a week schedule was an important aspect due to the professor's greater dedication to pedagogical activities, with the opportunity of planning activities thoroughly; proximity with the coordination and institution and participation in alignment meetings.

Only the core courses of the last three years of the undergraduate program were taken into account, as they were mostly taught by professors from the dentistry department and included the introduction of clinical training. Based in the integrated curriculum model proposed by the institution, the first training years cover the courses that are common to all programs of the Health Sciences Center.

Regarding the duration, we have considered five years or more because it represents the minimum period for the completion of the bachelor's degree in dentistry. The time of teaching experience was important as it allows professors to incorporate institutional values.

According to such criteria, 30 professors were eligible to participate in the research. However, it was not possible to include them all, as some of them were on leave, absent for travel or refused to participate. Finally, the sample comprised 23 professors that agreed to contribute to the study.

The research data was collected in September and October 2014 through a documentary analysis and semistructured interview, guided, respectively, by scripts.

In the documentary analysis of the politicalpedagogical project of the dentistry program, we have focused on the formative assessment, following the above steps: Characterization of the document; Coding of the analysis unit; Grade recording, schematics, diagrams or other synthesis methods; Critical Analysis.

The semi-structured on-campus interview was carried out by the researcher herself, according to the availability of teachers. The goal of the interview was to acquire information, insights and more accurate and detailed attitudes about the formative assessment in said course. Interviews lasted 20 to 25 minutes on average.

To ensure proper data confidentiality, the interviews were recorded with the subject's permission and then transcribed in full. All recordings have been stored in dedicated computer programs. The subjects were identified 
by letter $\mathrm{P}$ followed by a random number, to guarantee their anonymity.

Research data analysis took place from October 2014 to February 2015. The content of the course's Pedagogical Project was initially analyzed, observing the time frame and the historical-political context in which it was drafted.

Data of the semi-structured interviews was handled according to the thematic content analysis proposed by Minayo, which consists in discovering the core meaning that make up any communication, which presence or frequency means something to the target object [16], unfolding in the three stages: pre-analysis, data exploration and treatment of the obtained results and interpretation.

The project was submitted to the Ethics \& Research Board of the State University of Ceará and was approved by such Board in September 2014 (Consolidated Report No. 792,847).

\section{RESULTS}

23 professors were interviewed, $56.5 \%$ of which were women and $43.5 \%$ were men. The average age of the research subjects was 44 years. The teacher's average time of graduation was 21 years. All interviewees hold a postgraduate degree: five of them held a postgraduate degree, ten of them held a masters' degree and eight of them were Ph.Ds.

In their speeches, the main subjects were as follows: the difficult task of assessing - challenges for all education subjects; the educator's view on the contribution of assessment to the professional training. The categories will be presented and exemplified with the view of each interviewee, confronted with the aspects of the PoliticalPedagogical Project of the course and the literature.

\section{The hard task of assessing - challenges for education stakeholders}

The main obstacle in the assessment process, pointed out by the teachers, is related to the obligation of assigning a score and ranking the students' performance. This obligation of attributing value to students starts early in school life. The process has both objective and subjective aspects and turning the learning process into numbers is necessary to follow up students throughout the course. Concern about assessment evaluation criteria shows teachers are worried about being unfair. Student also expect to reach a certain score and are more worried about their marks, rather than about the knowledge to be acquired.

[...] Establishing the score, assigning a number to the student. This is quite complicated and difficult, as much as we have previously set criteria. To assign a certain value to each student, in that moment is complicated and may be unfair [...] (P12).

[...] The problem we face is that students always think they need to reach a certain score, because that is what they have been taught since school. So, we will work with adults in the same way. Forget about the score [...] That is not the focus [...] Student still prize the grading system, they do not care about the knowledge acquired, and sometimes the grade itself may be unfair (P7).

The assessment in this regard has an administrative purpose, according to the teacher, and concerns the quantification of the student's knowledge. Attributing a grade, establishing if such grade is satisfactory or unsatisfactory is not enough for the education institution. The grade has the role of passing, ranking, selecting and excluding.

In this process, in order to quantify the students' knowledge, assessment criteria should be well defined, institutionally-wise, with the participation and awareness of all stakeholders involved, and should be constantly reviewed. A proper definition of criteria, considering the goals of each discipline and the profile of graduates, reduces the teacher's guilt regarding the possibility of issuing an unfair judgment.

Assessment results in the shape of grades end up creating a ranking, which leads to comparisons between students. This logic demonstrates the bureaucratic nature that impoverishes the learning process.

Academic performance in theoretical and theoretical-practical courses, recording grades, review of ascertainments and final exams are governed by resolutions issued by the education institution and are not described in the Pedagogical Political Project. The PPP recommends that evaluation criteria should be previously defined and agreed upon at the beginning of the academic term between students and teachers in an educational plan. The document does not bring any guideline to govern criteria used in different assessment tools. 
[...] Another problem is that the university's criteria and norms impose a grade, a number and the teacher have to adapt. An often-subjective assessment has to somehow become objective, has to turn into numbers, which is difficult for us. It will always be difficult, no matter the background and experience we have, formative assessment must be somehow subjective, but it needs to express a value, thus becoming objective [...] (P16).

The teacher should feel as part of the pedagogical project, including in the definition of assessment criteria. And he/she should not just adapt to pre-established criteria. Some teachers have described that the grade is only a number assigned to students, so they can move forward in the course or not, taking into account that often passing a certain course is a requirement to enroll in other courses. It is worth mentioning that one teacher said that if he could choose, he would not use grades at all, since they are not as essential as the students' knowledge for the training process. The difficulty of quantifying a student is understandable, but should be overcome, as it is necessary to measure the students' performance and from that measurement, to make the right decisions.

\section{The educator's view on how formative assessment contributes to professional training}

The influence of formative assessment on the education depends on how the stakeholders understand such educational practice and the resulting experience. For most of the interviewees, the assessment contributes to improve the students' performance, working as a motivator in the teaching-learning process. However, it can be seen as a synonym for pressure, punishment and dispute and may not have a positive influence on their education.

[...] I think the assessment should be somehow motivating, encouraging students to look for something. It should serve as a motivator in the pursuit of growth and even if the result is bad, students must go through it to reach their goals [...] (P4).

Assessment as part of the learning process demands a different teaching approach. Teachers must show students that assessing is inherent to human beings and it is imperative in order to adjust educational activities and support their development.

[...] Assessment can serve as a dispute for students. There is always one who wants to score higher, wants an acknowledgment for that and it becomes a huge deal for them [...] They should not see it this way [...] (P8)

The traditional ranking approach must be overcome by seeking self-assessment- based personal goals that aims to transform the learner into an active subject who can learn and participate in the educational process, according to the interviewees.

This is a very difficult debate. Because if you ask students, most of them would prefer to not have any assessment or exam, because they can only see the pressure side of it. They do not understand how important it is [...] I think the assessment has a positive influence on their education, mainly because it encourages and channels their studies. Students begin to pay attention to a certain subject they did not understand much after making a mistake in their assessments. Students come into college with no maturity and no responsibility. Exams make them study. (P21)

These statements show the teachers' concern in clarifying the intention of the assessment process and overcome the negative side, but the strategies that will be used to reach such goal are not clear.

[...] They should see the assessment as something within their training process. And all stages of their training are necessary to development a certain professional profile [...] Human beings do not like to be judged, but this should be faced and understood as something beneficial as well. The world is assessing them every moment and they must be prepared [...] (P23)

The educator must use assessment methods that are in line with the methodologies used to demystify the threat, the authoritarianism and the pressure triggered in students. Assessment methods should be based on a reflection on the relevance of each of them to the production of knowledge.

In the institution's political-pedagogical plan, the relevance of the assessment is not highlighted and must be rather expressed in the document guiding the teaching practice. The PPP needs to be more comprehensive and also flexible to fit the students' learning needs. It should also be made available to all stakeholders of the teachinglearning process, so they can use it as a guide.

\section{DISCUSSION}

Data from the Federal Council of Dentistry shows that most (54.7\%) of dental surgeons in Brazil are women. 
This gender trend is not different in the Northeast region [17]. Regarding the gender of teachers within this study, the effective entry of women into university courses that were previously considered as 'masculine courses' affects the design of new social roles and opens new perspectives for the promotion of equality. [18]. However, we can still find in literature studies showing the highest percentage of male teachers in undergraduate dentistry courses [19]. The average education time among teachers within this study is similar to what the one found among dentistry professors of the State University of Londrina, with an average of 23 years of training time and 15 years of teaching time [19].

Dentistry professors face many challenges regarding legal requirements, in confrontation with the transformation of formal education, combined with the necessary training experiences. Extended teacher training, in addition to formal education, may be one of the ways to face the challenges that the legislation imposes to dentistry teachers [20].

Teachers talk about how difficult it is to assign a value for students in the assessment process, with both objective and subjective features. The pedagogical assessment process requires a previous definition of criteria that will guide this process, and both teachers and learners know what has to be developed, what still needs to be further worked and issues that need to be changed. In order to make it work in practice, clear assessment criteria must be established, in line with principles that will serve as a basis for judgment. In other words, principles that foster integration among the stakeholders involved in the assessment process [21].

Teachers mention that assigning a score allows them to judge, but it narrows down a student's performance or ability to a certain number, letter or concept - which suggests an extreme reductionism in the educational process. According to teachers, assessing, when expressed as quantitative data, scores, is difficult because learning is a rather qualitative process, as if knowledge, skills, abilities and attitudes could be strictly measured from a neutral instrument. The idea that the formative assessment is expressed as a simple number, or a ranking, may be seen as a narrowing process, since numbers do not reflect the learning process as a whole [7].

It is justified to assign grades / concepts in order to search elements that indicate the students' development, as well as the development of indexes by governments, allowing creating a national education quality benchmark
[22]. The grade or concept assigned to students must have, for each teacher, its own meaning, which results from the mastery of their work process as a whole [23].

For Luckesi [24] the grade is an official recording method, considering the students' learning, which must express quality based in what they were taught. On the other hand, he criticizes that, in practice, grades at school have a life on their own, as they were a "quantity of quality".

According to what we heard, students need to understand how important the assessment is for their training process. In this regard, Bagio et al. [25] emphasize that the assessment needs to arise from discussions in schools, in order to understand its different roles, its scope and to break down myths around it.

According to teachers participating in this study, assessment must provide continuous growth, fulfilling its role of diagnosing, strengthening and allowing growth. The assessment is the time in the teaching-learning process that allows their stakeholders to review the path they are taking, criticize it, interrupt it and change it, make new demands for the future and anticipate new steps along the way [26].

It should be motivating, in order to encourage commitment to the learning process, so the student can master and incorporate values, skills, competences and knowledge [22]. For Wiliam [27], the assessment is a key point in an effective education and it allows us to find out if a certain set of training activities was conducive to learning, a thought that aligns with dentistry professors who participated in this study.

For Chaves [28], assessment practices in higher education must be (re)thought, with the intention to value knowledge that students bring from their background and to lead them to search new knowledge. This knowledge determine their desires for learning, motivation and interest in the subjects introduced. Experiences lived in the classroom by teachers and students need to be tuned so that the assessment practices do not serve for punishment but rather for promotion.

In many contexts, the assessment still has a punishing and ranking purpose, based in a score or measurement unit, but it all depends on the purpose to which it is intended. A new assessment approach, dissociated from punishment and concerned with the integral development of learners, would focus on their emancipation [26] 
Another highlight was the ranking and sorting approach, as seen by students. This is a traditional notion and refers to the students' performance rating [29]. The assessment is a complementary and intrinsic element of the teaching-learning process that goes beyond the rating and reductionist scope of assigning grades or concepts to pass or fail students in the course [30].

Educational guidelines should provide more comments about the academic performance, and assessment criteria should be often discussed and built together with the institution, teachers and students, determining their values in such a way to facilitate judgment. The teacher, according to institutional provisions that must be expressed in such document, must be able to measure the students' performance and just then start making decisions. Another point worth considering is the short time taken to consolidate the curricular reform that is taking place in dentistry courses in Brazil [13] and the short time since the establishment of an integrated curriculum in the institution at issue.

The PPP of higher education institutions will have to be based on a pedagogical approach that is transformative, emancipating, liberating and sympathetic, focusing on training professionals who are fully aware of their responsibilities and duties [21].

\section{CONCLUSION}

Even though the grade is not the key element of the process, teachers must be prepared for this administrative and institutional requirement, establishing assessment criteria in their planning, according to the goals of each course, which should be presented and previously discussed with the students.

For teachers, assessment should foster and encourage learning, but they recognize the punishing and push effect that it still causes on the process and that must be overcome.

In order to attach a new meaning to the assessment process, the program should be based on a curricular pedagogical project supported by guidelines describing the inherent risks of the process, in order to avoid exclusion and discrimination.

The intention of this research was not to exhaust the discussion about the proposed subject, but rather to encourage reflection on assessment practices in higher education institutions in health sciences, focusing on the dentistry degree, as well as to inspire changes in the assessment process that will favor the development of critical and thoughtful dental surgeons.

Future studies need to investigate the students' view on formative assessment, providing broader considerations on such process, comparing the views of all players involved. The political pedagogical project must be built with the active participation of all the education stakeholders and should invest in the permanent training of teachers so they can assess students in a clear and consistent manner, thus determining the meaning of this practice in the educational context.

\section{Collaborators}

VF CARNEIRO and AMC PEQUENO contributed to the design of the study. MFAS MACHADO collaborated in the delimitation of the study object and interpretation of data. DML AGUIAR contributed to data analysis and discussion. C CARNEIRO helped to data analysis and interpretation. RF CARNEIRO contributed to the collection and interpretation of data.

\section{REFERENCES}

1. Luckesi CC. Avaliação da aprendizagem na escola: reelaborando conceitos e recriando a prática. 2 ed. Salvador: Malabares Comunicação e Eventos; 2005.

2. Saviani D. As concepções pedagógicas na história da educação brasileira. Texto elaborado no âmbito do projeto de pesquisa "O espaço acadêmico da pedagogia no Brasil", financiado pelo CNPq, para o "projeto 20 anos do Histedbr". 2005; 20:21-27.

3. Luckesi CC. Avaliação da aprendizagem escolar. $18^{a}$ ed. São Paulo: Cortez; 2006.

4. Saul AM. Avaliação emancipatória: desafio à teoria e à prática da avaliação e reformulação do currículo. São Paulo: Cortez; 1988.

5. Demo P. Professor do futuro e reconstrução do conhecimento. Petrópolis: Vozes; 2004.

6. Capello C. Avaliação e o novo cenário da educação. Revista FGV Online. 2014;3(1):4-10.

7. Marinho P, Fernandes $P$, Leite $C$. A avaliação da aprendizagem: da pluralidade de enunciações à dualidade de concepções. Acta Sci Educ. 2014;36(1):151-162.

8. Souza AML. Avaliação da aprendizagem no ensino superior: aspectos históricos. Rev Exitus. 2016:2(1):231-254.

9. Cardelli DT, Elliot LG. Avaliação por diferentes olhares: fatores que explicam o sucesso de escola carioca em área de risco. Ensaio: Aval e Polít Públicas Educ. 2012;20(77):769-98. http:// dx.doi.org/10.1590/S0104-40362012000400008 
10. Brasil. Senado Federal. Coordenação de Edições Técnicas. Lei $n^{\circ}$. 9.394, de 20 de dezembro de 1996. Estabelece a Lei de diretrizes e bases da educação nacional. Brasília: Senado Federal; 2017. Disponível em: <https://www2.senado.leg. br/bdsf/bitstream/handle/id/529732/lei_de_diretrizes_e_ bases_1ed.pdf>.

11. Brasil. Conselho Nacional de Educação. Câmara da Educação Superior. Resolução CNE/CES 3/2002, de 4 de março de 2002. Institui Diretrizes Curriculares Nacionais do curso de graduação em Odontologia. Brasília: Conselho Nacional de Educação; 2002. Disponível em: <http://portal.mec.gov.br/ cne/arquivos/pdf/CES032002.pdf>

12. De Camargo CCO, Mendes OM. A avaliação formativa como uma política includente para a educação escolar. Rev Educ Polít Debate. 2013;2(2):372-390.

13. Zilbovicius C, Araujo ME, Botazzo C, Frias AC, Junqueira $S R$, Junqueira CR. A paradigm shift in predoctoral dental curricula in Brazil: evaluating the process of change. J Dental Educ. 2011;75(4):557-564.https://doi.org/10.1002/j.00220337.2011.75.4.tb05080.x

14. Sordi MRLD, Lopes CVM, Domingues SM, Cyrino EG. O potencial da avaliação formativa nos processos de mudança da formação dos profissionais da saúde. Interface. 2015;19:731742. https://doi.org/10.1590/1807-57622014.1079

15. Fadel CB, Baldani MH. Percepções de formandos do curso de odontologia sobre as diretrizes curriculares nacionais. Trabalho. 2013;11(2):339-354. https://doi.org/10.1590/S1981-7 7462013000200005

16. Minayo MCS. O desafio do conhecimento: pesquisa qualitativa em saúde. 14 a ed. São Paulo: Hucitec, 2014.

17. Barbosa KGN, Dias JN, Cavalcante GMS, Nóbrega LM., Granville-Garcia AF, D'ávila S. Formação e perspectiva do mercado de trabalho sob o olhar de alunos de Odontologia. Pesquisa Brasileira em Odontopediatria e Clínica Integrada. 2013;13(1). https://doi.org/10.4034/pboci.2013.131.13

18. Melo Costa S, Durães SJA, De abreu, MHNG. Feminização do curso de odontologia da Universidade Estadual de Montes Claros. Rev Ciênc Saúde Coletiva. 2010;(15). https://doi. org/10.1590/S1413-81232010000700100
19. Santos LP, Linhares DS, Carniel T, Feldens CA, Fontanella VRC. Estudo do perfil docente nos cursos de odontologia da região Sul. Rev Inic Científica ULBRA. 2013;(8).

20. Franco LLMM, Soares ÉF, Martorell LB, Marcelo VC. O professor do curso de odontologia: sua formação e os desafios frente às exigências atuais. Rev Profissão Doc. 2009;9(20):57-74. https://doi.org/10.31496/rpd.v9i20.235

21. Vasconcelos CMCB, Backes VMS, Gue JM. Avaliação no ensino de graduação em enfermagem na América Latina: uma revisão integrativa. Enferm Glob. 2011;55(23):118-139.

22. Meneghel SM, Kreisch C. Concepções de avaliação e práticas avaliativas na escola: entre possibilidades e dificuldades. In: IX Congresso Nacional de Educação. Curitiba: PUC-PR; 2009.

23. Fontanive NS. A divulgação dos resultados das avaliações dos sistemas escolares: limitações e perspectivas. Ensaio: Aval e Polít Públicas Educ. 2013;21(78): 83-100.

24. Luckesi CC. Sobre notas escolares: distorções e possibilidades. São Paulo: Cortez; 2014.

25. Bagio VA, Pereira AL, Costa C. Um modelo para as conexões entre currículo e avaliação da aprendizagem. Ens Tecnol Rev. 2017;1(2):170-190. https://doi.org/10.3895/etr.v1n2.7466

26. Castanho ME. Docência no Ensino Superior: desafios contemporâneos. Rev Evidência. 2017;13(13):13-22.

27. Wiliam D. What is assessment for learning? Stud Educ Eval. 2011;37(1):3-14. https://doi.org/10.1016/j.stueduc.2011.03.001

28. Chaves S. Avaliação da aprendizagem no ensino superior: realidade, complexidade e possibilidades. São Paulo: USP; 2003.

29. Chuieire MSF. Concepções sobre a avaliação escolar. Estud Aval Educ. 2008;19(39):49-64. http://dx.doi.org/10.18222/ eae193920082469

30. Tronchin DR. Métodos avaliativos da aprendizagem no bacharelado na Escola de Enfermagem da Universidade de São Paulo. Avaliação. 2017;22(3):758-771. https://doi. org/10.1590/s1414-40772017000300010

Received on: 29/10/2018

Final version resubmitted on: 8/5/2019

Approved on: 18/6/2019 